Studia Anglica Posnaniensia 52(4), 2017

doi: 10.1515/stap-2017-0020

\title{
THE BURDEN OF 'WHITE' SUGAR: PRODUCING AND CONSUMING WHITENESS IN AUSTRALIA
}

\author{
STEFANIE AFFELDT* \\ University of Heidelberg
}

\begin{abstract}
This article investigates the history of the Queensland cane sugar industry and its cultural and political relations. It explores the way the sugar industry was transformed from an enterprise drawing on the traditional plantation crop cultivated by an unfree labour force and employing workers into an industry that was an important, symbolical element of 'White Australia' that was firmly grounded in the cultural, political, nationalist, and racist reasoning of the day. The demographic and social changes drew their incitement and legitimation from the 'White Australia' culture that was represented in all social strata. Australia was geographically remote but culturally close to the mother country and was assigned a special position as a lone outpost of Western culture. This was aggravated by scenarios of allegedly imminent invasions by the surrounding Asian powers, which further urged cane sugar's transformation from a 'black' to a 'white man's industry'. As a result, during the sugar strikes of the early $20^{\text {th }}$ century, the white Australian sugar workers were able to emphasize their 'whiteness' to press for improvements in wages and working conditions. Despite being a matter of constant discussion, the public acceptance of the 'white sugar campaign' was reflected by the high consumption of sugar. Moreover, the industry was lauded for its global uniqueness and its significance to the Australian nation. Eventually, the 'burden' of 'white sugar' was a monetary, but even more so moral support of an industry that was supposed to provide a solution to population politics, support the national defence, and symbolize the technological advancement and durability of the 'white race' in a time of crisis.
\end{abstract}

Keywords: Australia; sugar cane; consumerism; racism; commodity racism; political consumption; nation building; white sugar.

Heidelberg University, Transcultural Studies, Marstallstr. 6, 69117 Heidelberg, Germany, email: saffeldt@gmx.net 


\section{Introduction}

The Brisbane Courier was rather adamant in its position: though it is "not unnatural" that the Australian public is distressed by the financial strain the heightened sugar price put on them, it must be realised that what is at stake is not just any industry but the "white man's industry". In view of the overpopulated Asian neighbourhood, the defence against the "land-hungry myriads of the East", who consider the landscapes "a most tempting prize", and against the "black or brown men, millions of whom swarm at our very doors", is imperative. Therefore, the question of 'white sugar' concerns more than its mere "economic side", which is "not the only side, nor necessarily the most important one". What is at stake is "[t]he very existence of Australia as a nation", and this, in turn, is dependent on "the effective protection of sugar". The survival of the cane sugar industry concerns the whole Australian Commonwealth: it is every member's duty to bear their "burden of 'white'sugar" (Brisbane Courier 1912: 6).

There are three strands of discourse addressed in the Brisbane Courier that are representative of the societal atmosphere at the time of Federation. They are programmatic for this article, which aims to investigate the relationship between 'White Australia' and cane sugar, which was eventually 'refined white' and 'produced white'. Accordingly, taking the allusion to the 'white man's burden' as a thread, the present article divides into three parts. Firstly, the white man's industry looks at how the historical socio-political burden of sugar cane as a plantation crop cultivated by an unfree labour force influenced the establishment of the Queensland sugar industry and affected the drastic demographic and social changes at the end of the $19^{\text {th }}$ century. Secondly, the land-hungry myriads of the East sheds light on the racial burden the retaining of the southern continent put on its European occupiers. Against the backdrop of the 'White Australia' culture, this section identifies ostensible external enemies and internal foes, i.e., an alleged danger from the outside and social tensions from within. It describes the anticipated potential of 'white sugar' in the defence of the thinly populated northern parts of Australia against the allegedly imminent hostile land occupation by foreign forces. Thirdly, the white consumers' burden examines how the monetary strain generated by the high prices of Australian sugar was counterbalanced by accentuating the consumers' moral duty to the country. The concomitant consumerist strategies translated racism and nationalism into everyday activities and encouraged a wide-spread participation by the white population.

Furthermore, today's historical hindsight allows us to follow the strands of discourse beyond the temporal (rather than theoretical) scope of the Brisbane Courier article into the 1920s and 1930s, when Australian consumerism reached 
a peak in campaigns for nationalist consumption that were spearheaded by 'white sugar'.

Taking into account the existing literature on cane sugar and its discriminative power, this discourse-analytical examination of Australian 'white sugar' aims toread the debates of the time (in particular in the newspapers) in parallel with discussion in the secondary literature. Admittedly, there is an extensive body of literature dealing with 'White Australia' at the political level, addressing aspects such as the assumed invasion by Asian powers and the South Sea Islanders as cane workers. Historiographies of the sugar industry delineate the successes and failures of the industry in terms of the cultivation processes and the expansion of the industry, as well as detailed historical studies of the varying cane districts. However, despite its political and societal significance around the turn of the $20^{\text {th }}$ century, and the then nationwide discussion about its relation to 'White Australia', literature investigating the Queensland sugar industry and its sociopolitical connections remains sparse (Affeldt 2014: 32-38).

\section{The 'white man's industry'}

The warning cry that inspired this article alludes to the notion of the 'white man's burden', which was synoptically addressed in the famous poem of the same name (Kipling 1899). This originally global long-term project - that is, Europe's sense of mission, the willingness and preparedness emanating from a Eurocentric worldview that entitled its messengers, purportedly gifted in culture and progress, to carry forth their concepts of culture and education - also gave legitimation to the expansion of imperialism. Together with the "feeling of chosenness", it made "imperial encroachments" seems like a "civilizing obligation" (Hund 2014: 17). Cane sugar's reputation as a catalyst for “"westernization' or 'modernization' or 'development"' (Mintz 1986: 193) was created within the context of colonialism and closely intertwined with the implementation of power structures in foreign countries. Therefore, sugar cane was the perfect agent of colonialism - it functioned both as the catalyst of land appropriation and an allegedly God-given task to put the soil to 'good use'. This was a task for which, as the numerous 'race hierarchies' ostensibly testified, many of the native populations were suspected of being incapable of, because they were lacking in the appropriate cultural and technical developments (Wright 2002: 130).

In the same vein, the Indigenous population had allegedly failed to accomplish this task. The British occupation of the continent had been legitimated by referring to the land as 'terra nullius', i.e., a land belonging to no one. The entitlement to the continent was thus theoretically tied to the proviso of improving the soil through cultivation (Fitzmaurice 2014: 322-329). The seizure of Australia and its legitimation were therefore gradually underpinned, 
on the one hand, by a purported necessity to educate the Indigenous population that was seen as culturally lagging behind and, on the other, by the expansion of the British settlement, which was accompanied by the opening up of land for agricultural industries. One of these crops was, of course, sugar cane.

By the time of the Brisbane Courier article, in 1912, the cane sugar industry of Queensland had already become an important asset to Australian nation building. The industry had dramatically increased its economic viability from its first (failed) attempts at the time of the arrival of British convicts in New South Wales in 1788 to its (permanent) establishment in the mid-1860s to the proclamation of the Commonwealth of Australia in 1901. Moreover, by now, its symbolic value for 'White Australia' far surpassed its financial importance.

Sugar cane arrived in Australia in January 1788 (Queensland Sugar Corporation 1997: 62f). At this time, however, it was already more than an innocent food plant. On its journey around the globe - from New Guinea to Asia to the Mediterranean area to the Americas and Africa - sugar cane had been 'racially', politically, and culturally charged, until the nutritional plant initially grown as a garden crop returned to Oceania as a plantation crop produced with unfree, generally 'black', labour (Abbott 2008, Aronson \& Budhos 2010, Macinnis 2002, Mintz 1986).

Though the "link between sugar cane cultivation and slavery which was to last until the nineteenth century became firmly forged" on the Mediterranean sugar plantations (Galloway 1989: 42) and though African slaves were already familiar to European eyes (Martin 2012: 13f), slavery was not yet irrefutably linked to skin colour and most slaves originated from Europe. It was not until the mid- $15^{\text {th }}$ century, when sugar cane cultivation had translocated to the islands off the Portuguese coast, i.e., to Madeira and the Azores, to the Canary Islands and then south to São Tomé (Baxa 1937: 11, Galloway 1989: 59), that the connection between sugar and slavery was added the dimension of colour (Baxa \& Bruhns 1967: 15, Macinnis 2002: 24-27, Mintz 1986: 30). By the transference of sugar cane across the Atlantic Ocean to the Americas, in particular Brazil, the connection between the plantation cultivation and slave labour was further consolidated. In the seventeenth century the saying "Without sugar, no Brazil; without slaves, no sugar; without Angola, no slaves" (Schwartz 1992: 12) emphasized the triangle that included the colonial land-taking and the taking of people for the production of a foodstuff consumed in Europe.

This interaction of European expansion endeavours (colonial land-taking) and cost-effective production conditions (slavery) in the 'New World' fostered a rapid dissemination of cane sugar. After it had been a luxury good for the upper classes for centuries, the amounts of sugar that reached Europe increased and the price fell accordingly (Mintz 1986: 95). Over the course of the $18^{\text {th }}$ century, sugar was consumed in ever greater amounts - and with an increasing chemical purity that 
found expression in its ever whiter colour - even by the lower classes of the society. By the mid- $19^{\text {th }}$ century, it had virtually become a nutritional necessity for every member of British society - so much so that during the latter half of the century "the biggest sucrose consumers ... came to be the poor" and sugar "the first mass-produced exotic necessity of a proletarian working class" (Mintz 1986: $148,46)$. However, it was more than simply a foodstuff. In a foreshadowing of what would later be called political consumerism, cane sugar brought together Europeans in their act of consumption while the arduous work was done in the colonies. In this respect, sugar's chromatic whiteness was combined with the burgeoning concept of social 'whiteness' - the exploitation of 'blacks' stood in tandem with joint consumption by 'whites'.

While the usage of cane sugar was still in the process of trickling down Britain's social hierarchy, the First Fleet arrived at the beach of Sydney Cove. Consistent with the ideological baggage now attached to sugar cane - its political and social charge as a product of 'black' labour - the workers that were to cultivate the crop, and thus work off their debts to society, were the convicts. Here a translocation of the discriminatory element now attached to sugar cane was shown to be underhandedly transferable to the lower classes of the own society, and the qualifier 'black' was for the first time revealed as being as much a racial as a social one.

Because of the unsuitable climatic conditions in the subtropics, the cultivation of sugar cane in the new colony left much to be desired. It was not until the European settlers expanded their occupation to the tropical parts of the continent that large-scale production became feasible. The circumstances of cane sugar's eventual successful cultivation again combined elements of land appropriation (the British settlement spreading northwards) and the traditional social position of the sugar work force (the plantings took place in the vicinity of Moreton Bay, today Brisbane), which, as a place of secondary punishment, domiciled the colony's repeat offenders.

Albeit, when, by the early 1860 s, sugar cane was ready to be grown in commercially viable dimensions, the abolition of convict transportation had cut off the resource of the (inevitably) servile labour. It was out of the question for cane to be cultivated by free sugar planters, because it was certain that the plantation crop necessitated an extensive and therefore inexpensive work force. Attempts were made, at times even successfully, to employ the Indigenous population in cane cultivation, but overall they were said to be an unreliable resource of labour, not least because their superior knowledge of the surrounding areas allowed them to abscond and easily evade the settlers (Affeldt 2014: 132-152). It seemed, therefore, more advisable to locate a substitute for convict labour from a geographically different context. This new labour resource was found on the close-by islands of the New Hebrides (today 
Vanuatu) and the Solomon Islands. The South Sea Islanders were - partly by force, partly by misleading - brought to the cane fields to work (Saunders 1982: 20-25). Their employment conformed to the traditional concept of employing 'black workers', and extensive plantations became the mode of cultivation.

Altogether, from 1863 to 1904, circa 62,500 'Pacific Islanders', as they were then called, were brought to Queensland (Berry 2000: 8). From the beginning, however, the introduction of the foreign labourers was accompanied by a public agitation over the seeming revival of slavery, which even the passing of the 'Kidnapping Act' of 1872 could barely silence (Banivanua-Mar 2005: 308, Phillips 2000). The purportedly humanitarian regulations, which made mandatory licences for recruitment and demanded the Islanders' assent to the labour contracts, could not betray the racist logics at work. When the colonial attorney-general asserted that, in the legal sense, it was "not possible to kidnap a person of a savage race if he was brought within the protection of the law" (Bramston in 1871, cited in Saunders 1982: 21) and further evoked images of the Europeans' as the civilizers and saviours of the 'coloured races', he alluded to the paternalistic notion of the 'white man's burden'.

In its Eurocentric worldview, it emphasized a responsibility of the allegedly superior 'white people' to uplift the 'coloured people' by European means of education and religion. As a by-product this was also imputed in the recruitment of South Sea Islanders which purportedly constituted their 'rescue' from their allegedly detrimental social situation and a future enslavement by their own communities (Brown 2007: 203). Their coming to Queensland was portrayed as an improvement in their quality of life, purportedly even by themselves, since, as the former Premier of Queensland claimed, South Sea Islanders "enjoy the steaming heat [in the cane fields], and nowhere do you find kanakas more happy than on the Queensland plantation" (Brisbane Courier 1884: 3) ${ }^{1}$.

The opponents of the so-called 'labour trade', in turn, evoked threatening images of 'black labour' in terms of their social and biological dimension. Socially, the employment of the South Sea Islanders was said to constitute a substratification of the working class with low-standard workers - this stood in contrast to the alleged fairness and equality of Australian society. Biologically, the presence of 'primitive' men without women or families allegedly encouraged miscegenation and was thus considered a danger to the racial purity of Australia, whose nation's hygiene was also risked by bringing such carriers of 'exotic' diseases into the country.

1 The term 'kanaka' is said to be derived from the Hawaiian word for 'man' or 'people' and is used for the group today acknowledged as South Sea Islanders, historically called Pacific Islanders. The critical secondary literature considers it derogatory. See, for example, Evans, Saunders \& Cronin (1989: 163) who compare 'kanaka' to the term 'nigger' of the US-American South. 
The subsequently increasing opposition to the employment of South Sea Islanders by the labour movement and their demand for 'white workers' in the Queensland sugar industry was, first of all, an ideological campaign that was based on the valorisation of the workers' 'whiteness' (Affeldt 2010: 105-111). A cursory look at the history of the working class in Australia shows that class relations had from early on been shaped by questions of race. While the convicts were neither socially (Nichol 1986: 3ff) nor ethnically homogenous (see Pybus 2006), they could experience the effects of "negative societalization" (Hund 2014) in contradistinction to the original population. With the Indigenous Australians identified as instigators of conflicts, and thus as ultimately to blame for their punishment (Kiernan 2007: 292), retribution against them was affected immediately: settlers, convicts, and the police united not only in "imagined communities" (Anderson 1999) but in retaliation campaigns and punitive expeditions which often bordered on genocidal massacres (Kiernan 2007: 13f) and are now even explicitly discussed as genocide (Tatz 1999: 33).

In the latter half of the $19^{\text {th }}$ century, however, the emancipated convicts and free workers experienced that this "racist symbolic capital" (Weiß 2010: 3756), which was activated by the Europeans' solidarity against the Indigenous population, was not feasible in other contexts, in particular when they stood in competition to highly exploitable 'non-white' labour. The first culmination of white workers' agitation took place on the goldfields, where the growing class tensions and the fury against the ruling class were discharged by directing the fury against those they deemed racially inferior competitors, and "initiated the first organised racist campaign against the Chinese" (Jensen 2005: 141).

Though this anti-Chinese agitation promptly found expression in immigration legislation, the potential threat against the purportedly morally and racially higher-standing European workers prevailed and was emphasized again in the labour struggles of the last decades of the $19^{\text {th }}$ century. This became evident, for instance, in the Seaman's Strike of 1878-79 (Curthoys 1978), which was caused by the Australasian Steam Navigation Company's replacing of the AngloAustralian ship crews with Chinese crews. The class dispute between the AngloAustralian seamen and the steam company was negotiated by the former with the leverage of racist (and in this case racial) solidarity that established the company as traitors to their own race and found broad support among the public as well as in the Queensland government, who sided with the European seamen. The local Townsville Herald stated that the strike was founded on a "social principle which is shared by all classes", since it was "not a question of class against class, but a question of race against race" (Townsville Herald, 30.11 .1878 ('principle') and 11.12.1878 ('question'), both cited in Griffiths 2009: 7).

The demands of the labour movement developed on the same lines. The campaign for the sugar industry to become a 'white man's industry' was not so 
much a socio-economic demand but rather an evocation of the central element of Australian identity: 'whiteness'. Though unemployment was high in the depression times before Federation (Davison 1985), attempts to employ European workers in the cane fields proved to be a problematic endeavour. Those preferred for work in the cane fields, British-Australians, were not only deterred by the perceived 'white unfitness' for life and labour in the tropical climate (Anderson 2005: 75) but even more by the ideological connections of cane sugar with slave labour. In addition the presence of allegedly inferior cane workers, i.e., South Sea Islanders, seemed to confirm these associations and kept white Australian workers from seeking employment.

For this reason, it was certain; an employment of European sugar workers was only possible if these ideological, and empirical, connections could be dissolved. This could only be achieved by a deconstruction of the sugar industry as a 'black industry' and its reconstruction as a 'white man's industry', that is to say, via the expulsion of its traditional workers. This, however, was only achieved by pressure from the other colonies, whose leaders considered the presence of 'black labour' as detrimental to the 'white nation', and the politicization of the labour movement in the form of the Labour Party, who stood for "total exclusion of coloured and other undesirable races" (McMullin 1991: 44).

All of this found expression in one of the first pieces of legislation of the Commonwealth which made compulsory the repatriation of the South Sea Islanders. The Pacific Islanders Labour Act of 1901 was one of two pillars of 'White Australia' - the other being the Immigration Restriction Act that predominantly restricted Asian immigration. The two acts accomplished the concerted effort to prevent the presence of 'non-white' people in Australia, or, as the attorney-general remarked: "The two things go hand in hand and are the necessary complement of a single policy - the policy of securing a "White Australia"" (Alfred Deakin, September 1901, cited in Lake 2003: 354f).

While the Pacific Islanders Labour Act provided the necessary frame for a demographic change in the sugar industry, the actual situation continued to show how much the argumentation by the labour movement to 'whiten' the sugar industry had to commence as an ideological struggle. White workers still largely refrained from seeking employment in what had for a long time been labelled "nigger work for a dog's pay" (Figaro 1884: 3). This thought prevailed in everyday discourse, in political cartoons, and in rhymes like: "It's just as clear as figgers, | Sure as one and one makes two, | Folks as make black slaves of niggers | Want to make white slaves of you" (Tocsin 1901: 1).

The unwillingness of white, i.e., in particular northern European, workers to be permanently employed in the industry, necessitated further ideological 'whitening': freeing the work in the cane fields from suspicions of slavery and inferiority. It took another five years accompanied by strikes, organized by the 
sugar unions that slowly emerged after Federation, and negotiations with planters, to improve the situation for the white sugar workers. The situation eventually escalated into the extensive 'Sugar Strike', which began in June 1911 - the "first major, prolonged and acrimonious industrial dispute" (Armstrong 1983: 106). Here, 'class' was eventually drowned by 'race' when the unions experienced broad support from other unions but even more so from the nation-wide public which supported the claim that "if the sugar company cannot support married men it is not an industry fit for the white men, or fit for the white man's country" (Argus 1911: 7). The strike expressed the demand for the conversion of racist symbolic capital, credited to the white workers based on their contradistinction to the "racial others', into tangible "wages of whiteness" 2 in the form of improved working conditions and wages deemed appropriate for white workers. In particular by claiming their racial and cultural distinction from their South Sea Islander predecessors, the European-Australian workers eventually achieved the validation of their 'whiteness' and exacted economic compensation.

In the end the transformation of the Queensland sugar industry into the 'white man's industry' was the result of a network of unionist, political, and nationalist demands, which argued racistly and were supported by a culture that glorified 'whiteness' and was necessarily borne by the mainstream society.

\section{3. "Land-hungry myriads of the East"}

Very likely the development of the "white man's industry" would have proceeded quite differently without the ideological influences of the time. 'White Australia' culture was rooted in the anxious societal climate before Federation and contributed to the preservation of an industry that was seen as providing, beside its economic contribution to Australia, answers to its biopolitical problems and defence against an allegedly imminent hostile takeover.

In late-19 $1{ }^{\text {th }}$-century Australia the "white man's burden" became the plight to defend the very same country the 'white man' was actually still in the process of taking into possession. Its protection against the dangers of the "yellow peril", the feared invasion by Asian powers, became a top priority. The specific isolated geographical position - far away from the culturally close mother country but in near proximity to countries that were culturally and racially deemed totally different - made Australia a fragile outpost of the 'white race' (Markus 2003: 178). With the waning of 'white supremacy' at the end of the $19^{\text {th }}$ century, this position was considered more dangerous than ever, in particular with regards to the ostensibly overpopulated Asian countries seeking

In the northern American context, David Roediger's Wages of Whiteness (2007) has demonstrated how the Irish-Americans accomplished to be gradually included into the white society by locating themselves in contradistinction to the African-American and Chinese co-workers. 
an outlet in the empty landscapes of the Australian continent. The notion of 'white supremacy' had been intricately conceived, established, legitimized, and evidenced throughout the $18^{\text {th }}$ century. At the end of the $19^{\text {th }}$ century, it came under challenge and turned into a global "crisis of whiteness" (Bonnett 2005: 8). The 'white man's burden' seemed to turn into a 'white man's bane' when the colonized increasingly came under the suspicion of turning against the colonizers and the need to preserve 'white supremacy' became more urgent.

The Worker was the mouth-piece of the labour movement from its establishment in September 1892. It critically monitored the developments in the sugar industry and strongly argued in favour of its 'whitening'. Concerning the 'crisis of whiteness', for the Worker (1904: 1) the global project of educating and civilizing was beginning to retaliate against the 'whites' and, furthermore, had become a (socio-economic) burden on the shoulders of the working classes. Its cover cartoon "The White Man's Burden” of December 1904 (Figure 1) refers to this classist turning upside down of the responsibility and depicts a group called "The Unemployed" waiting in front of the "Charities Department". One of them is approached by 'John Bull', the national personification of England, and is handed a "Xmas Degradation". The unemployed man rejects this and, referring to the aftermath of the Second Anglo-Boer War, states "You have ruined South Africa, and now you would ruin me, too!"

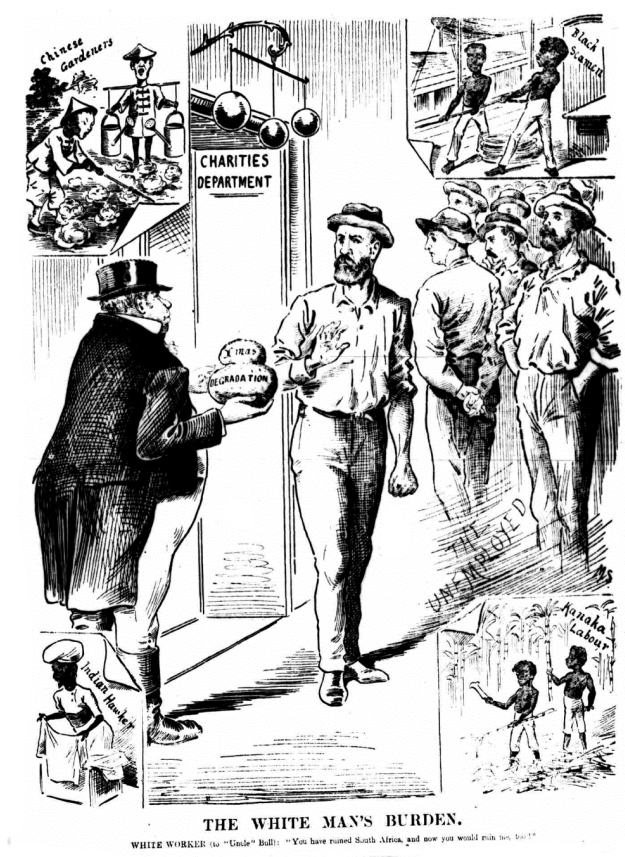

Figure 1. The White Man's Burden (The Worker, December 1904) 
The cartoon displays some issues of this 'white man's burden' the labour movement identified at the end of the century. The scene outside the charity department is girded by smaller portrayals of non-Europeans in Australia. The men referred to as "Chinese Gardeners", "Black Seamen", "Kanaka Labour", and "Indian Hawker" are not only visually marked as being different from the "white workers". Their nominal racial classification is expanded by their depiction 'in action' - according to their labels all of them are employed, whilst the European-Australian men in the middle, hands in their pockets, are forced to be "idle through no fault of their own", as the accompanying article told the readers (Qui Vive 1904: 3). This referred to the dissatisfaction of the employers recruiting 'coloured labour' instead of 'white' and thus also located the problem in the ranks of the capitalist class. The author of the article continues to describe the dire situation created by increasing numbers of unemployed, which he sees located in a "system of refined savagery we call "civilization". He then outlines the situation in South Africa which he considers "exploits of blood" in favour of a "capitalism [that] is robbery under arms". It is the soldiers - about 5000 of them were Australian miners and artisans and a number of them were prominent unionists (Lake \& Reynolds 2008: 221) - who had to pay for the interests of the capitalists with their lives. Imperialism was no longer a noble enterprise enlightening and promoting the 'dark' corners of the world; it was no longer the 'white race' ruling over other peoples. Here, the commonality of 'race' has decomposed into a dissimilarity of 'class'. In the cartoon, a representative of British ruling classes is unmasked as a capitalist 'race traitor' - he turns against the 'white heart' of Australia (the working class) by privileging the employment of workers from abroad for maximization of profits, ignoring the detrimental effects to the Australian society. Thus, the 'burden' of veritable 'white men' has by implication become their survival in the face of imperial pretensions.

Also, the Boer War was observed in its meaning for the global power balance as parts of the British Liberal Party, the short-lived Liberal Imperialists, hoped for a British victory to "open the way to securing greater justice for the native population and the coloured community in South Africa" (Lake \& Reynolds 2008: 133). Albeit, consolidation of the discriminatory relationship between 'black' and 'white' was evoked when, shortly after the end of the Boer War, the British High Commissioner maintained that "[a] political equality of white and black is impossible. The white man must rule, because he is elevated by many, many steps above the black man; steps which it will take the latter centuries to climb, and which it is quite possible that the vast bulk of the black population may never be able to climb at all" (Thompson 1960: 6). In this context, "white supremacy" might seem "entrenched economically and politically by 1900"; after all, the comfortable living conditions of both the British and the Afrikaners in South Africa "relied on the hyper-exploitation of 
unskilled black labour" (Jones 2015: 55) and thus were located in the same classical division between 'black labour' and 'white beneficiaries' in which Australian sugar consumers had found themselves before Federation.

But in the global context, this statement was an increasingly desperate invocation of the alleged superiority of the 'white race'. The first decades of the $20^{\text {th }}$ century saw many anti-colonial uprisings and suppressed 'racial Others' grew more organized in their fights for independence. Existing fractures in the European self-image significantly increased with the Japanese victory over Russian forces at Tsushima in 1905 (Jukes 2002; Wolff et al. 2007). The formers' success in the Russo-Japanese war was a shock to the Western world - a "deadly blow at the dominance of the West" (Worker 1905: 2) that "challenged and ended the white man's expansion" (Matthews 1925: 27, cited in Bonnet 2005: 5). The necessity of preserving 'white solidarity' seemed even more urgent.

Far from being the incursions of gossip gazettes and insane prophets of doom, the fears of a coming to power of so-called 'coloured races', the challenges to 'white supremacy', and a particular role of Australia in this scenario were discussed by many scientists of the day. Charles H. Pearson, and later Lothrop Stoddard and Madison Grant, warned of a heightened proliferation of the 'coloured people' and its impact on colonialism. Pearson imagined a future in which the "globe [was] girdled with a continuous zone of the black and yellow races" (Pearson 1893: 89). He also predicted imminent detrimental effects for the Western world when the colonized were "no longer too weak for aggression or under tutelage but independent" and would rise up against the colonizing powers (Pearson 1893: 89). While he believed that the "evanescent races", i.e., Indigenous Australians, South Sea Islanders, and other indigenous people, were about to succumb to the 'natural law' of 'survival of the fittest' and give way to the 'white race', he considered in particular the Chinese people "too numerous and sturdy to be extirpated" that easily (Pearson 1893: 33-34). After personally getting familiar with the Australian situation for several decades, he had a prominent place for the continent in his theory. Australia's "fear of Chinese immigration" was an "instinct of self-preservation, quickened by experience". Even worse, it was "not the Englishman in Australia alone, but the whole civilised world, that will be the losers" if the self-protection of Australia failed (Pearson 1893: 16).

Stoddard, too, underlined the need for Australia to defend itself from becoming the 'outlet' for Asia's 'surplus' population. He explicitly emphasized the necessity of a special defence in Australia, "white in blood as the European motherland" (Stoddard 1920: 3), as one of the "true bulwarks of the race" and as the last keeper of "race heritage, which should be defended to the last extremity no matter if the costs involved are greater than their mere economic value would warrant" (Stoddard 1921: 226). 
In the 1930s, Madison Grant wrote forth this special position of Australia (and New Zealand) as white outpost "where the natives have been virtually exterminated by the whites" and which were "developing into communities of pure Nordic blood [that] will for that reason play a large part in the future history of the Pacific" (Grant 1936: 79).

These scientific deliberations provided the background for a literary genre that enjoyed popularity in Western cultures at the end of the $19^{\text {th }}$ century. Having emerged in Britain, ${ }^{3}$ invasion novels proved especially popular in Australia (Walker 2005, Ross 2006). Its remote and isolated geographical location in the 'Far East', on the one hand, and its mainstream population that was desperately attempting to remain British in terms of culture and homogeneous in terms of race, on the other, caused the publishing of numerous works after the late 1870s. Beginning with George Ranken's The Invasion in 1877, Edward Maitland's Battle of Mordialloc in 1888 and Ernest Favenc's The Last of Six in 1893, 'invasion angst' as a literary subject continues until today - for instance, in John Marsden's Tomorrow, When the War Began (1993) and its sequels.

The invasion novels were published in book form but were also disseminated as serials in labourite newspapers of the day. One of the most famous was written by William Lane, the first editor of the Worker and a front figure of the Australian labour movement, and was published in twelve parts in another journal he had founded, the Boomerang. In his dystopian narration White or Yellow? A Story of the Race-War of A.D. 1908 Lane describes how, after the relaxation of immigration restriction by an Anglo-Asia-affiliated Queensland government, the Chinese "over-ran everything", "monopolised a score of important industries" (surely amongst them the profitable sugar industry), "sat in Parliament, directed State departments" rendering Australia "more and more distasteful to the Caucasian peoples". In the end the "race-fight for life and supremacy" is won by the white Australians who recalled the "truth' of distinction by skin colour, and in the "real' fight of "white against yellow" the Chinese - "passing northwards like great droves of cattle" - are expelled from Australia (Lane 1888: 18.2.88, 9; 14.4.88, 9; 5.5.88, 6).

Kenneth Mackay's novel The Yellow Wave of 1885 addressed the socio-political significance of the sugar industry more directly. His recreation of then real-life politician Thomas Mcllwraith - a staunch defender of employment of South Sea Islanders - was the "Dictator of Queensland", "head and front of a powerful oligarchy, whose plantations covered the North ... and whose cheap alien labour created dividends unknown in the days when a white population existed" (Mackay 2003 [1885]: 89). By making him claim that “" [s]ocialism and anarchy are dead, ...

3 One of the first invasion novels, George T. Chesney's The Battle of Dorking (1871) envisioned a Germany invasion in the context of the Franco-Prussian war. 
the unions crushed, and, thank God, we have won back the confidence of the foreign capitalists. Trade was never so flourishing, for, through our introduction of cheap labour, the plantations have at last been made to pay" (Mackay 2003 [1885]: 89), Mackay paints a dire picture of the future in which the agents of the sugar industry have forsaken every last bit of 'racial loyalty' to the Australian workers and have placed profits over the proliferation of the white nation.

Like many other invasion novels, these examples spoke of possible hostile land occupation by foreign powers, mostly China and Japan. Their contained colour racism placed those who invaded the country in contradistinction to the white Australians who were considered the rightful proprietors of the continent. The associated stereotypes declared the 'invading hordes' as being devoid of any social distinctions and humanity - in the novels and in the political cartoons of the time they were often depicted by using symbols of multitudes, like locusts, octopi, or elephants.

Most importantly, not least in the context of 'white sugar' and its significance in Queensland, the 'empty north' was a major concern for the invasion novels. They identified the subjectively underpopulated parts of Queensland (and today's Northern Territory) as the weak points of the nation. These stretches of land were seen as the most likely stepping stones for the enemies approaching from the north.

Thus, the discourse about populating the 'empty north' in favour of defence against the 'yellow peril' found entrance into everyday culture of white Australians. Besides the daily dosage of local and national politics in the newspapers and the perusal of invasion novels, a visit to local theatres added to the substance of 'White Australia' culture. The most pertinent example for such cultural contributions is a piece called 'White Australia: Or, the Empty North' by Randolph Bedford, which warned its audience against the vulnerabilities of the northern parts of the continent and possessive approaches by Chinese forces (McGregor 2016: 12).

All these narratives had in common, firstly, the identification of a hostile power which was then made a common 'external enemy' who stood in contradistinction to a society which, secondly, had an urgent need to overcome internal societal tensions - in particular class gaps - to defend itself against said enemy.

Besides 'external enemies', however, the novels also dealt with 'foes within', when they addressed the societal disharmony of Australian society and its internal social tensions. As in the fictive case of the 'Dictator', labour movement's historical notion of the employers and property owners as crucial danger to nation-building and cohesion of 'White Australia' by their fostering of immigration and employment of 'non-white' labourers was taken up in these visions of Australia's dire futures as well as the perception that politicians preferred debating to taking political and defensive actions against alleged 
imminent approaches by 'neighbouring foes'. In the narratives it was the common man of Australia who was the main victim of a hostile takeover, because the dire situation was blamed on the leaders' inability to act, the capitalists' greed for money and power, and the urban upper classes' preference of engaging in sports and pursuing hobbies instead of facing 'reality'.

The narratives also identified white women as being societal weak points. While the white Australian male was considered the defender of the "white nation', women's role was seen as being bearers of racial purity - but their endangerment of society lay in their purported susceptibility for Asian men. White women were crucial to health and proliferation of 'white society', yet they were also seen as those who would put it at serious risk. This was, on the one hand, self-caused due to their own deficiency of being unable to withstand the lure of opium dens and 'exotic' men and, on the other hand, they would become targets of war crimes, like abduction, rape, and murder.

The debate in favour of 'white sugar' at the end of the $19^{\text {th }}$ century drew on these elements of 'White Australia' culture: the fear of an imminent hostile take-over by Asian powers - namely the Chinese sheer numerical superiority and the Japanese military perilousness - and the necessity, in particular for Australia as a self-proclaimed outpost of Western civilization in the Far East, to remain racially 'white'. In the focus of the debate surrounding demographic changes in the sugar industry, bio-political deliberations played a decisive role. In the face of a numerical superiority of the suspected Asian invaders, the thinly populated 'empty North' had little to offer. While original British occupation of the continent had been legitimated based on an alleged lack of agricultural appropriation by Indigenous Australians, this became an urgent problem at the end of the $19^{\text {th }}$ century when British rights of possession of the continent were critically discussed.

Though, thanks to sugar cane and a few smaller industries, occupation of the northern parts of the continent was underway, time seemed to run out - in particular when seeing the population distribution on a larger scale. An assumed overpopulation of Asian neighbouring countries, in the minds of Australian thinkers, would cause a discharge of societal overpressure on the deserted Australian shores. That Indigenous Australians, who were (of course) present in the northern stretches of land, would not be counted as population almost went without saying. That South Sea Islanders, who were still working in the sugar industry around 1900, would not be much of a help in the face of an 'Asian invasion' seemed most probable. A growth in the taking-up residence of Chinese, and increasingly also Japanese, people - not least due to their recruitment in the sugar industry when European workers refrained from offering their labour - would impair the population deficit even further. 
Sugar cane was seen as the perfect agent of permanently populating the 'empty North' with sugar planters, sugar workers and their families. Along these lines, the "Sugar Growers of Australia" advertised their industry's potential in the 1930s (Figure 2) and incited the willingness of the Europeans to engage in sugar cultivation - this, in turn, called for social, financial, and political means to further the dissolution of the connection of sugar cane and ('black') slave labour.

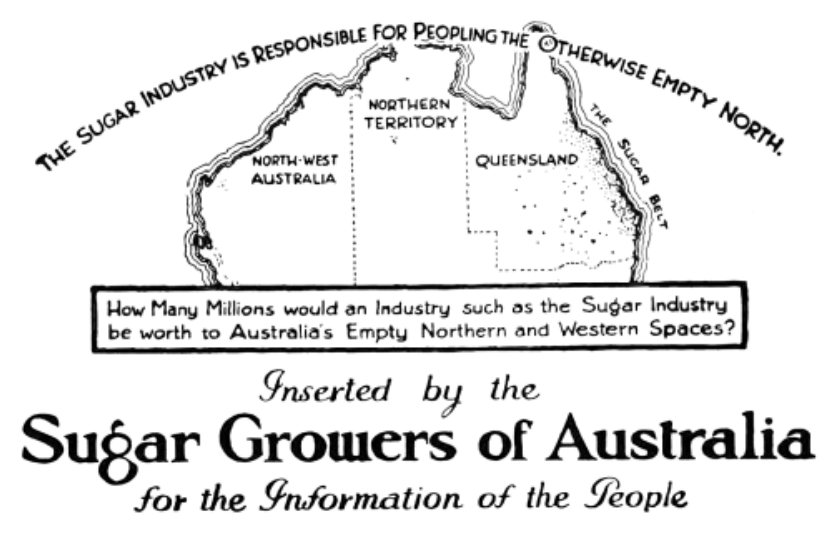

Figure 2. 'White' sugar against the 'empty North' (Advertiser, 13.4.1932: 18)

The demographic change of the sugar industry at the turn of the $20^{\text {th }}$ century would probably not have taken place without the momentum of 'white culture', which intensified in the context of the danger from outside in the 1880s. It not only affected the negotiations of Queensland with the other colonies during the process of Federation but was then also used by the labour movement as a leverage to emphasize their racist symbolic capital in order to receive actual 'white wages', such as higher wages and improved working conditions. Albeit, despite its successful transformation to a 'white man's industry' the struggle over 'white sugar' was far from over. The maintenance of the sugar industry as the "bulwark of White Australia" (Argus 1923b: 7) in the face of a constant challenging of its system of financial and political subsidies by some members of the public was as arduous as the transformations.

4. White consumers' 'burden'

By 1901, cane sugar was a product of absolute mass consumption and, despite an embargo of cane sugar from overseas, Australia was constantly amongst its top per capita consumers. Sugar had become the popular 'poster food' of nationalist consumption - this refers to the processes by which 'whiteness' was 
(re)produced in Australia. The efforts to maintain 'white sugar' in the early $20^{\text {th }}$ century constitute the third 'white man's burden': a financial strain brought about by an intricate system of excise and bounties - enforcing the embargo while counterbalancing the increased price necessitated by higher wages for the white sugar workers - was only the monetary expression of a broader moral obligation to the 'white nation'. The latter was firmly rooted in the notion of 'white supremacy' and the desire to keep Australia 'racially pure'.

After the sugar industry had been turned into a 'white man's industry', the consumption of sugar refined and produced 'white' became an individual's service to the nation. This, apart from being a financial burden, comprised a moral duty that was even more significant. Rhetorically, this circumstance was moist poignantly phrased by the Prime Minister William Hughes in 1922, who explained to the Australian population that "you cannot have a White Australia in this country unless you are prepared to pay for it. One of the ways in which we can pay for a White Australia is to support the sugar industry of Queensland" (Argus 1922: 29).

Theoretically, the issue is explained by Michel de Certeau, who saw in everyday habits "another production, called 'consumption"” (Certeau 1988: 82) and with this already addressed an important means of both spreading the idea of 'white Australianness' though the mainstream society and dealing with it on a day-to-day basis. 'Whiteness' cannot 'exist' anywhere without being a topic of constant discussion, redefinition, and questioning. The intimate intertwining of politics with culture and everyday life reveals that, at the beginning of the $20^{\text {th }}$ century, 'whiteness' was at the heart of Australian national identity.

However, far from 'whiteness' being invisible or a general norm (Dyer 2010), the inclusive and exclusive dimensions of 'whiteness' were matters of constant debate. When Britishness as the prime feature for Australianness was increasingly replaced by an emphasis on 'whiteness', even those who were considered Europeans were no longer automatically admitted to all spheres of society. This is shown by the example of Italians and other Southern Europeans, who initially entered the sugar industry in the 1890 s and, in even higher numbers, in the first decades of the $20^{\text {th }}$ century. Discrimination against them was based on the assertion that they were 'not white enough' (Affeldt 2014: 210-240).

In the debate surrounding the social 'whiteness' of sugar Southern Europeans were a case of dispute. In terms of population politics some argued that the tropical parts of the country were impossible to settle because of the unfavourable climate, and Southern Europeans were deemed European enough to stand up against the 'yellow peril' but 'southern' enough to be able to withstand the tropical heat. This, too, was only an extension of a perspective which drew on intra-Italian bisection and declared Southern Italians to have "a considerable admixture of African blood" while Northern Italians had "a 
considerable streak of German blood" which, nonetheless, "seems to have degenerated" (Bulletin 1907, quoted in Dewhirst 2008: 42).

In the discourse of the day, Italians - along with other Southern Europeans, like Maltese and Greeks - were characterised by numerous epithets. These were either social ascriptions, linking them to laziness and criminality, or racist descriptions, which inferred an African element or dehumanized them by comparing them to apes (Andreoni 2003: 84; Cresciani 2003: 57).

Already before Federation, the labour movement discussed the necessity to fight against the presence of Italians in the cane fields; this hostility increased when the sugar planters recruited Italians as strike breakers during times of industrial unrest. During the reconstruction of their industry, the plantation owners also desired to encourage the immigration of workers from Italy in order to counteract possible labour shortages brought about by the growing opposition to Asian and Pacific Island cane workers. Those who arrived via 'assisted passages', i.e., by governmentally supported immigration schemes, for work in the cane fields were the target of many a discriminatory campaign.

Most notably this racist resentment was pushed forward by the workers' press asking "First the coolie, then the kanaka, now the Italian! Isn't it time our own flesh and blood had a chance?" (Worker 1890: 2). Here, 'flesh and blood' was more than a figure of speech: it reflected the elements of the Australian workers' struggle for 'fair' wages that began on the goldfields in the eighteen fifties, continued on the ships towards the end of the nineteenth century, and was far from over when the white sugar workers struck in the early twentieth century. Flesh and blood were the symbolical equivalents of class and race. The earned income was supposed to enable the worker to live an adequate life and populate the continent, but it was also to be obtained by those who were considered deserving, meaning predominantly the British-Australians but certainly not foreign workers. These discussions surrounding Southern Europeans showed the malleability and internal differentiations of 'whiteness' and continued until far into the $20^{\text {th }}$ century ${ }^{4}$.

Thus, even though both sugar consumers and producers were in the majority of European descent, their admittance to the 'white society' was by no means unquestioned. This, in turn, provoked a questioning of the support for a sugar industry that allegedly was not as 'white'as it declared itself to be. Not only an argumentative closeness to the labour movement, but also the delimitation between 'true' Australians and Italians was explicitly addressed when the Federal Housewives' Association decried employment of Italian workers "to the

During the late 1960 there were still physical fights with British men over the discrimination of Italian men. It was not until the early 1970s that the metaphor of the "black Italian" eventually began to vanish (Moraes-Gorecki 1994: 316). 
exclusion of [...] our own Australian men" (Argus 1923a: 6). The Association further claimed that "an Italian industry" should not be supported and preferred to have the ban on "black-grown sugar" from overseas lifted, in order to lower the price of sugar to one "that would enable workers to live decently" (Sydney Morning Herald 1927: 11). In this the qualifier 'black' revealed its simultaneous racial and social element - the former in the 'blackness' of sugar cane from overseas, the latter in the 'blackness' of sugar cane grown by those Europeans who were not deemed 'white enough' and had also been functioning as strike breakers during the sugar strikes.

These challenges to 'white sugar' necessitated constantly legitimating the support of the sugar industry by the politics and the public of Australia. In this process, the supporters of 'white sugar' were able to activate elements of political consumerism that had its heyday during the latter half of the $19^{\text {th }}$ century.

The beginnings of consumerism are commonly dated back to the mid- $19^{\text {th }}$ century, in particular the first world fair at the Crystal Palace in London. The Great Exhibition of the Works of Industry of all Nations opened in May 1851 (Richards 1990: 17-71). It was the first in a long row of international exhibitions displaying new technological achievements and scientific developments - amongst them, of course, "cheapening" sugar cane from the colonies (Anon. 1851: 116). It allowed visitors of all societal strata to participate in what could be called a celebration of consumption. This socially broad admission to the exhibition was also a symbolical admission of all visitors to consumption society. While this equality would surely be disputed in an actual buying situation, displays devoid of price tags nourished the illusion of participation by all. Though they might be lacking actual economic capital, a visit to the exhibition provided them with something even more valuable. It allowed the visitors to count themselves amongst the ranks of a society that, when compared with Indigenous societies, was characterized by progression, history, and knowledge.

In a similar vein, but already a century before, Adam Smith in The Lectures on Jurisprudence had advised the lower classes to turn their observations to the outside of society. He suggested that the poor, striving for wealth but not able to increase it, should compare their social situation not with the wealthy classes of their own society but with those in higher social positions of indigenous societies. They would then discover that their "luxury is much superior to that of many an Indian prince, the absolute master of the lives and liberties of a thousand naked savages" (Smith 1978 [1763]b: 563).

World fairs and international exhibitions provided the best arguments to do so. With the relocation of the Crystal Palace to its new location in Sydenham, the exhibition was expanded by an 'exotic' addendum. In contrast to the collections of European commodities, anthropological departments were 
henceforth organized. These displayed, surrounded by 'outlandish' animals and indigenous artefacts, plaster casts of indigenous people from other countries, mostly the own colonies. In subsequent years the establishment of so-called 'human zoos', where 'authentic' savages performed their ways of life for the visitors, followed (Hund 2013: 26).

Right from the start, therefore, the emerging consumer society was intimately connected with notions of 'white supremacy'. This was taken a step even further in product advertisements. For instance, 'Pears' Soap', in their 1890 advertisement, directly referenced "The White Man's Burden" as their slogan and claimed that "[t]he first step towards lightening is through teaching the virtues of cleanliness. Pears' Soap is a potent factor in brightening the dark corners of the earth as civilization advances, while amongst the cultured of all nations it holds the highest place - it is the ideal toilet soap". ${ }^{5}$ This not only referred to the global project of 'uplifting the native' but also alluded to further discriminatory images of alleged physical, moral, and other impurities. Therefore, the exhibitions, consumption and associated processes helped populate theories of the race sciences in the $18^{\text {th }}$ and $19^{\text {th }}$ century, whose findings, in turn, continued to inform their advertising and exhibition strategies. "Commodity racism" (McClintock 1995) emerged as a commodified version of scientific racism - in particular, it contrasted alleged 'white' superiority with 'black' inferiority and often did this by praising colonial commodities.

It is not a total coincidence that, also by the mid- $19^{\text {th }}$ century, cane sugar coming from the Caribbean had finished its journey through the social strata of British society and was finally becoming a mass product. With the increasing consumption of cane sugar in all strata of society, its potential as a social binding agent became obvious. Though the community of sugar consumers was still hierarchically divided by the availability of differing qualities of the sweetener - from the cheaper molasses to the expensive purest white sugar they were united by their benefitting from the colonial situation. Here the drawing of racist boundaries was put into everyday practice. Like other colonial products, e.g., tea, tobacco, and coffee, a great part of the production took place in the countries of origin. The experienced 'inclusion by consumption' of the "powerful symbols of the empire" furthered the class- and gender-spanning consolidation of their consumers (Bickham 2008: 74), who were assured by these everyday activities that they belonged to a privileged group. Consumption of colonial goods by British consumers thus stood in contradistinction to the exploitation of those deemed 'racial Others'. Here the consumption functioned as more than a mere intake of calories; it signified appropriation and served the

$5 \quad$ For an example of the poster see

https://upload.wikimedia.org/wikipedia/commons/9/95/1890sc_Pears_Soap_Ad.jpg 
(re)production of social relations in the sense that "tactics of consumption ... lend a political dimension to everyday practices" (Certeau 1988: xvii).

Australian commodity racism followed its Western counterpart regarding the placement of white consumers in contradistinction to 'coloured' producers. The sharing in on the food culture by all strata of society was achieved even faster in the early colonial settlements than it was in the mother country (Affeldt 2014: 96-99). Starting with a customary awarding of cane sugar in convict rations, consumption of sugar had become an important element long before the establishment of the Queensland industry. Australian consumers were similarly united in their consumption of the 'home-grown' cane sugar as were their British relatives. For a while, Australian consumers could even see with their own eyes the implementation of the exploitation. Furthermore, the employment of South Sea Islanders for menial tasks also caused another benefit for white consumers: a process of collective elevation which then saw white workers as overseers in the cane fields.

In addition, tea, coffee, chocolate or any of the other colonial products imported to Australia all had in common this notion of 'white profit'. As consumption goods, sugar and tea had arrived at the same time on board the First Fleet. In the subsequent century, Australians had become some of the top capita consumers of both goods. Tea was imported, inter alia, from Java, India, and China and remained "the principal drink" of all classes until, at least, the 1930s (Symons 2007: 166).

Whilst Australians of the first half of the $20^{\text {th }}$ century had no problem sweetening their 'black' tea (or coffee or cocoa) with 'white' sugar and enthusiastically drank this concoction, it seemed obvious, at least for the supporters of 'white sugar', that a 'true' Australian must choke on 'black' sugar. Nonetheless, this attitude was often disputed, in particular by those in the southern parts of the country who were in favour of opening up the national market to the global sugar market. They pushed for an import of cheaper sugar. Australians "drink black-labour tea every day, therefore it will do [...] no harm to sweeten that tea with black-labour sugar", as an Adelaidean claimed in his letter to the editor (Craigie 1922: 12).

Other newspapers, especially in the northern states, replied to these criticisms of the 'sugar policies' by publishing sugar producers' statements, such as the large-scale advertisements commissioned by the "Sugar Growers of Australia" (Figure 3) in the 1920s and 1930s. These promotions drew on the longestablished fears of the 'yellow peril', the still unsolved problem of the 'empty north', and the identity-building 'White Australia' culture. In counterbalance to the comparatively high price of Australian cane sugar - essential to financing the 'white wages' and improved working and living conditions of the white sugar workers - stood the racist symbolic capital that was activated by the consumption 
of a foodstuff that reminded its consumers of their patriotic nationalism and their commitment to the survival of the 'white race'.

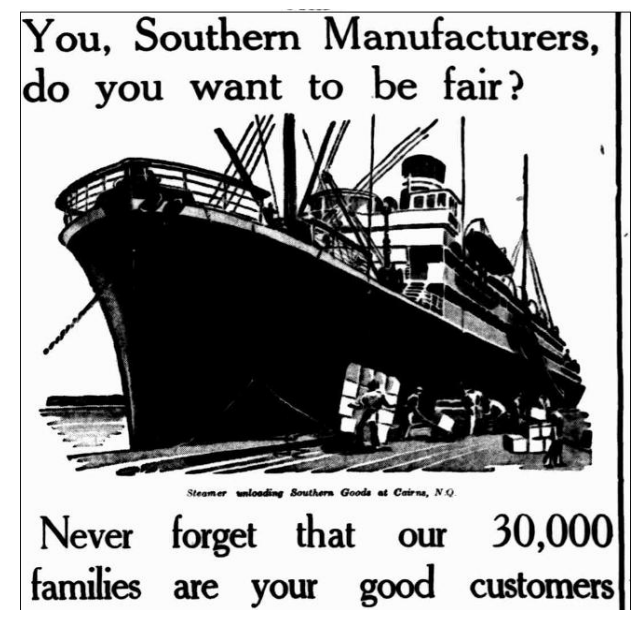

Figure 3. 'White' sugar is 'fair' sugar (Brisbane Courier, 19.4.1932: 9)

In this advert, the 'fairness ${ }^{6}$ of southern manufactures and their obligation to support the northern industry was addressed. The "30,000 families" who were the southern producers' customers were intimately connected to the Queensland sugar industry. To avoid unemployment and impoverishment of said families, the "fair price" granted by the Prime Minister's fixing of the raw sugar price could not be lowered any further, argued the accompanying text. Thus, it was the manufacturers who were to tip the scales either in favour of or to the detriment of all those northern people and with that were responsible for the success of life in the tropics with all further implications.

Campaigns like these were possible, because, in the case of 'white sugar', the groups of producers and consumers overlapped. Those who planted the setts and cut the cane and crushed the crop were also those who put the result into their tea. Overall, the subtle differences regarding commodity racism between 'black tea' and 'white sugar' sprung from the same logic. While use of the former endorsed classical colonial situations that had already been practiced in the mother country, the latter form of commodity racism conformed to ambitions to keep Australia racially homogeneous. Both had, of course, in common a hierarchical concept of the 'races' and the placement of the 'white race' at the top.

6 This advertisement provided a play on words with the term 'fair', which, in the understanding of the time, could mean "just, beautiful, white" (Kelen 2005: 218). The fairness was thus not only the demand for a just treatment but also once more questioned the capitalists' loyalty to their fellow 'white' Australians and their moral commitment. 
While consumption of sugar was thus an acknowledgement of the special situation of a sometimes fragile nation worth of protection (not least in favour of the whole 'white race' as Pearson had claimed in 1893), the consumption of other colonial goods validated Australians as being on the same beneficiary level as other white consumers of the Empire. In the end, for Australian consumers, the 'white people's burden' was not the civilizing of the 'others' but the exclusion of 'black', 'brown', and 'yellow labour' by gender-spanning, class-bridging consumption of products and purchase of a good that was favourable to nation and race and endorsed the 'White Australian' ideal.

\section{Conclusions}

The Brisbane Courier article cited in the beginning was written at a watershed moment of the history of 'white sugar' in Australia. By 1912, its historical roots, i.e., the establishment of a commercial cane sugar industry with the help of workers from the Pacific Islands, were not yet completely forgotten, yet they began to fade away in favour of a 'white' future. The Federation of the Commonwealth of Australia with its most important pillar - the 'White Australia policy' - provided the last step necessary for the demographic change to an industry that would only employ white workers. However, it took another uprising of the white working class in the form of the 1911 'Sugar Strike' in the previous year to initiate a social change in favour of 'white wages' and improved working conditions.

'Whiteness' in Australia was an often discussed issue. By the time, the Australian population was united as the Commonwealth of Australia, 'whiteness' was at the heart of the national identity. Cane sugar with its history of being a societal binding agent, as proved in Britain, did its reputation justice. While, initially, notions of the plantation crop cultivated by an unfree labour force influenced the search for a labour source, its ideological symbolism was highlighted after the turn of the $20^{\text {th }}$ century when both legislation and labour movement agitation pressed ahead with the 'whitening' of the sugar industry. Not long after the eventual social transformation, sugar producers jumped the bandwagon and drew on the image of sugar cane as a catalyst of populating the 'empty north' and thus providing resistance to the feared invasion by the 'yellow peril'. Support of the sugar industry, not only by other industries but also by consumers, was equated to a moral service to the (white) nation.

Thus, overall, the burden evoked by the historic subject of 'white sugar' can be seen as threefold: firstly, the metaphor reminds of the historic connection between imperialism and colonialism, i.e., the self-imposed mission to 'educate and civilize' colonized people (referred to as the 'white man's burden'), which accompanied the endeavour of cultivating sugar cane with slave labour to the 
benefit of the European consumers. Secondly, towards the end of the $19^{\text {th }}$ century, this global mission seemed to lead to retaliation against the colonizers, when attempts of the 'coloured people' to rise to power were challenging 'white superiority'. Australia's burden became its fortifying against the external danger by regulating immigration and adjusting its population politics, such as an intensified recruitment of white Australian workers in the cane fields. Thirdly, with Federation, Australia as the 'last bastion of the white race' based its social cohesion on the exclusion of those deemed 'undesired' and, in the case of 'white sugar', generated 'white solidarity' by utilizing campaigns of nationalist and racist consumerism, the financial and moral burden of which lay on the shoulders of the common people.

On the particular question of the survival of the Queensland sugar cane industry, the Brisbane Courier article claimed that "the duty is on the Commonwealth". In doing so it was as retrospective, knowing about the internal struggles that lay behind the sugar workers, as it was prophetical of the consumerist campaigns and imperatives that, as shown, were yet to come in the following decades. The Brisbane Courier asserted: "If white Australians will not, or cannot, do it", i.e., support 'white sugar', the consequences would be dire as it would have to be "admit[ted] that the White Australia policy has failed" (Brisbane Courier 1912: 6).

\section{REFERENCES}

Abbott, Elizabeth. 2008. Sugar: A bittersweet history. Toronto: Penguin Canada.

Affeldt, Stefanie. 2010. A paroxysm of whiteness. 'White' labour, 'white' nation and 'white' sugar in Australia. In Wulf D. Hund, Jeremy Krikler \& David Roediger (eds.), Wages of whiteness \& racist symbolic capital, 99-131. Berlin [et al.]: Lit Verlag.

Affeldt, Stefanie. 2014. Consuming whiteness: Australian racism and the 'white sugar' campaign. Berlin [et al.]: Lit Verlag.

Anderson, Benedict. 1999. Imagined communities: Reflections on the origin and spread of nationalism. (Revised extended edn.) London: Verso.

Anderson, Warwick. 2005. The cultivation of whiteness: Science, health and racial destiny in Australia. Carlton: Melbourne University Press.

Andreoni, Helen. 2003. Olive or white? The colour of Italians in Australia. Journal of Australian Studies 27(77). 81-92. DOI: 10.1080/14443050309387853

Anon. 1851. A guide to the great exhibition: Containing a description of every principal object of interest. London: George Routledge \& Co.

Argus. 1911. Sugar strike. The Argus. 3 August 1911: 7.

Argus. 1922. Mr. Hughes in Queensland. Sugar and the producers. Fanatic on white Australia. The Argus. 11 November 1922: 29. 
Argus. 1923a. Cost of sugar. The Argus. 12 April 1923: 6.

Argus. 1923b. Importance of industry. Bulwark of 'white Australia'. The Argus. 7 June 1923: 12. Armstrong, John. 1983. The sugar strike, 1911. In Denis Murphy (ed.), The big strikes: Queensland 1899-1965, 100-116. St Lucia: University of Queensland Press.

Aronson, Marc \& Marina Budhos. 2010. Sugar changed the world: A story of spice, magic, slavery, freedom, and science. Boston: Clarion Books.

Banivanua-Mar, Tracey. 2005. Consolidating violence and colonial rule: Discipline and protection in colonial Queensland. Postcolonial Studies 8(3). 303-319. DOI: $10.1080 / 13688790500231053$

Baxa, Jakob \& Guntwin Bruhns 1967. Zucker im Leben der Völker: Eine Kultur- und Wirtschaftsgeschichte. Berlin: Bartens.

Baxa, Jakob. 1937. Die Zuckererzeugung 1600-1850. Jena: Verlag von Gustav Fischer.

Berry, Michael. 2000. Refined white. The story of how South Sea islanders came to cut sugar cane in Queensland and made history refining the white Australia policy. Innisfail: Australian Sugar Industry Museum.

Bickham, Troy. 2008. Eating the empire: Intersections of food, cookery and imperialism in eighteenth-century Britain. Past and Present 198(1). 71-109. DOI: 10.1093/pastj/gtm054

Bonnett, Alastair. 2003. From white to Western. 'Racial decline' and the idea of the West in Britain, 1890-1930. Journal of Historical Sociology 16(3). 320-348. DOI: 10.1111/1467-6443.00210

Bonnett, Alastair. 2005. From the crisis of whiteness to Western supremacy. Australian Critical Race and Whiteness Studies Association Journal 1. 8-20.

Brisbane Courier. 1884. An interview with the ex-prime minister of Queensland. The Brisbane Courier. 24 September 1884: 3 .

Brisbane Courier. 1912. The burden of "white" sugar. The Brisbane Courier. 10 December 1912: 6.

Brown, Laurence. 2007. 'A most irregular traffic'. The oceanic passages of the Melanesian labour trade. In Marcus Rediker, Cassandra Pybus \& Emma Christopher (eds.), Many middle passages, 184-203. Berkeley: University of California Press.

Bulletin. 1907. (no title). The Bulletin. 14 March 1907: 6.

Certeau, Michel de. 1988. The practice of everyday life. Berkeley: University of California Press.

Chesney, George T. 1871. The battle of Dorking. Edinburgh, London: William Blackwood \& Sons.

Craigie, E. J. 1922. The sugar question. The Register. 17 June 1922: 12.

Cresciani, Gianfranco. 2003. The Italians in Australia. Cambridge: Cambridge University Press.

Curthoys, Ann. 1978. Conflict and consensus: The seamen's strike of 1878. In Ann Curthoys \& Andrew Markus (eds.), Who are our enemies? Racism and the working class in Australia, 48-66. Sydney: Hale \& Iremonger.

Davison, Graeme. 1985. Unemployment, race and public opinion: Reflections on the Asian immigration controversy of 1888. In Andrew Markus \& Merle C. Ricklefs (eds.), Surrender Australia? Essays in the study and uses of history: Geoffrey Blainey and Asian immigration, 101-111. Sydney: Allen \& Unwin

Dewhirst, Catherine. 2008. Collaborating on whiteness: Representing Italians in early White Australia. Journal of Australian Studies 32(1). 33-49. DOI: 10.1080/14443050801993800

Dyer, Richard. 2010. White. (Reprinted edn.) New York, NY: Routledge. 
Evans, Raymond, Kay Saunders \& Kathryn Cronin. 1989. Race relations in colonial Queensland: A history of exclusion, exploitation and extermination. St Lucia: University of Queensland Press.

Favenc, Ernest. 1893. The last of six: Tales of the Austral tropics. Sydney: The Bulletin Newspaper Company.

Figaro. 1884. Griffith's labour scheme. Queensland Figaro. 13 September 1884: 3.

Fitzmaurice, Andrew. 2014. Sovereignty, property and Empire, 1500-2000. Cambridge: Cambridge University Press. DOI: 10.1017/CBO9781139924306

Galloway, Jock H. 1989. The sugar cane industry: An historical geography from its origins to 1914. Cambridge: Cambridge University Press.

Grant, Madison. 1936. The passing of the great race: Or, the racial basis of European history. ( $4^{\text {th }}$ edn.) New York, NY: Charles Scribner's Sons.

Griffiths, Philip G. 2009. The heroic shameful role of labour: Mythology in the making of white Australia. Paper presented to the Legacies 09 conference, University of Southern Queensland.

hooks, bell. 1992. Eating the other: Desire and resistance. In bell hooks, Black looks: Race and representation, 21-39. Boston: South End Press.

Hund, Wulf D. 2013. Advertising white supremacy. Capitalism, colonialism and commodity racism In Wulf D. Hund, Michael Pickering \& Anandi Ramamurthy (eds.), Colonial advertising \& commodity racism, 21-68. Berlin [et al.]: Lit Verlag.

Hund, Wulf D. 2014. Negative Vergesellschaftung: Dimensionen der Rassismusanalyse. $2^{\text {nd }}$ edn. Münster: Westfälisches Dampfboot.

Jensen, Lars. 2005. Unsettling Australia: Readings in Australian cultural history. New Delhi: Atlantic Publishers \& Distributors.

Jones, Lee. 2015. Societies under siege: Exploring how international economic sanctions (do not) work. Oxford: Oxford University Press.

Jukes, Geoffrey. 2002. The Russo-Japanese war 1904-1905. Oxford: Osprey Publishing Ltd.

Kelen, Christopher. 2005. Hymns for and from white Australia. In Alfred J. Lopez (ed.), Postcolonial whiteness: A critical reader on race and empire, 201-231. Albany, NY: State University of New York Press.

Kiernan, Ben. 2007. Blood and soil: A world history of genocide and extermination from Sparta to Darfur. New Haven, CT: Yale University Press.

Kipling, Rudyard. 1899. The white man's burden. McClure's Magazine 12(4): 290.

Lake, Marilyn \& Henry Reynolds. 2008. Drawing the global colour line: White men's countries and the international challenge of racial equality. Cambridge: Cambridge University Press. DOI: $10.1017 / \mathrm{CBO} 9780511805363$

Lake, Marilyn. 2003. White man's country: The trans-national history of a national project. Australian Historical Studies 34(122). 346-363. DOI: 10.1080/10314610308596259

Lane, William. 1888. White or yellow? A story of the race-war of A.D. 1908. The Boomerang. 18 February 1888: 9, 25 February 1888: 8-9, 3 March 1888: 11, 10 March 1888: 9, 17 March 1888: 9, 24 March 1888: 9, 31 March 1888: 9, 7 April 1888: 10, 14 April 1888: 9, 21 April 1888: 9, 28 April 1888: 9, 5 May 1888: 6.

Macinnis, Peter. 2002. Bittersweet: The story of sugar. Crows Nest: Allen \& Unwin.

Mackay, J. A. Kenneth. 2003 [1885]. The yellow wave. A romance of the Asiatic invasion of Australia. (Ed. by Andrew Enstice \& Janeen Webb.) Middletown: Wesleyan University Press.

Maitland, Edward. 1888. The battle of Mordialloc: Or, how we lost Australia. Melbourne: Samuel Mullens. 
Markus, Andrew. 2003. Of continuities and discontinuities: Reflections on a century of Australian immigration control. In Laksiri Jayasuriya, David Walker \& Jan Gothard (eds.), The legacies of white Australia: Race, culture and nation, 175-190. Crawley: University of Western Australia Press.

Marsden, John. 1993. Tomorrow, when the war began. Chippendale: Pan Macmillan Australia.

Martin, Peter. 2012. Zucker für die Welt. Die Anfänge der Sklaverei und der Fabrikgesellschaft in Amerika. Berlin: Universitätsverlag der TU Berlin.

Matthews, Basil. 1925. The clash of colour: A study of the problem of race. London: Edinburgh Press.

McClintock, Anne. 1995. Imperial leather: Race, gender and sexuality in the Colonial contest. New York: Routledge.

McGregor, Russell. 2016. Environment, race, and nationhood in Australia: Revisiting the empty north. New York, NY: Palgrave Macmillan.

McMullin, Ross. 1991. The light on the hill. The Australian labor party 1891-1991. Melbourne: Oxford.

Mintz, Sidney W. 1986. Sweetness and power: The place of sugar in modern history. New York, NY: Penguin Books.

Moraes-Gorecki, Vanda. 1994. 'Black Italians' in the sugar fields of North Queensland: A reflection on labour inclusion and cultural exclusion in tropical Australia. The Australian Journal of Anthropology 5(1-2). 306-319. DOI: 10.1111/j.18359310.1994.tb00183.x

Nichol, William. 1986. Ideology and the convict system in New South Wales, 1788-1820. Historical Studies 22(86). 1-20. DOI: 10.1080/10314618608595733

Pearson, Charles H. 1893. National life and character: A forecast. London, New York: Macmillan \& Co. of Australia.

Phillips, Lawrence. 2000. British slavery after abolition. The Pacific trade. Race \& Class 41(3). 13-27. DOI: $10.1177 / 0306396800413002$

Pybus, Cassandra. 2006. Black founders: The unknown story of Australia's first black settlers. Sydney: University of New South Wales Press.

Queensland Sugar Corporation. 1997. Sugar Notes. Brisbane: Queensland Sugar Corporation.

Qui Vive. 1904. Bystander's notebook. Figures of misery. The Worker, 24 December 1904: 3.

Ranken, George (under the nom-de-plume W. H. Walker). 1877. The invasion. Sydney: Turner \& Henderson.

Richards, Thomas. 1990. The commodity culture of Victorian England: Advertising and spectacle, 1851-1914. Stanford, CA: Stanford University Press.

Roediger, David. 2007. The wages of whiteness. Race and the making of the American working class. ( $3^{\text {rd }}$ revised edn.) London, New York: Verso.

Ross, Catriona. 2006. Prolonged symptoms of cultural anxiety: The persistence of narratives of Asian invasion within multicultural Australia. Journal of the Association for the Study of Australian Literature 5. 86-99.

Saunders, Kay. 1982. Workers in bondage: The origins and bases of unfree labour in Queensland, 1824-1916. St Lucia: University of Queensland Press.

Schwartz, Stuart B. 1992. Slaves, peasants, and rebels. Reconsidering Brazilian slavery. Chicago, IL: University of Illinois Press.

Smith, Adam. 1976 [1759]. The theory of moral sentiments. In David D. Raphael \& Alexander L. Macfie (eds.), The Glasgow edition of the works and correspondences of Adam Smith (vol. 1.). Oxford: Clarendon Press. 
Smith, Adam. 1978 [1763]a. Early draft of part of The wealth of nations. In David D. Raphael \& Alexander L. Macfie (eds.), The Glasgow edition of the works and correspondences of Adam Smith (vol. 5.), 562-581. Oxford: Clarendon Press.

Smith, Adam. 1978 [1763]b. Lectures on jurisprudence. In David D. Raphael \& Alexander L. Macfie (eds.), The Glasgow edition of the works and correspondences of Adam Smith (vol. 5.). Oxford: Clarendon Press.

Stoddard, Lothrop. 1920. The rising tide of color against white world-supremacy. New York, NY: Charles Scribner's Sons.

Sydney Morning Herald. 1876. Legislative assembly. The Sydney Morning Herald, 18 August 1876: 3 .

Sydney Morning Herald. 1927. Housewives oppose the sugar embargo. The Sydney Morning Herald. 22 September 1927: 11.

Symons, Michael. 2007. One continuous picnic: A gastronomic history of Australia. Carlton: Melbourne University Press.

Tatz, Colin. 1999. Genocide in Australia. (Australian Institute of Aboriginal Studies Research Discussion Paper No. 8.) Canberra: Australian National University.

Thompson, Leonard M. 1960. The unification of South Africa, 1902-1910. Oxford: Clarendon Press.

Tocsin. 1901. Topical echoes. The Tocsin. 28 March 1901: 1.

Tweed Daily. 1925. Sugar industry. Bruce will safeguard. The Tweed Daily, 15 October 1925: 2.

Walker, David. 2005. Shooting Mabel: Warrior masculinity and Asian invasion. History Australia 2(3), 89.1-89.11. DOI: 10.2104/ha050089

Weiß, Anja. 2010. Racist symbolic capital: A Bourdieuian approach to the analysis of racism. In Wulf D. Hund, Jeremy Krikler \& David Roediger (eds.), Wages of whiteness \& racist symbolic capital, 37-56. Berlin [et al.]: Lit Verlag.

Wolff, David, Steven G. Marks, Bruce W. Menning, David Schimmelpenninck van der Oye, John W. Steinberg \& Yokote Shinki (eds.). 2007. The Russo-Japanese war in global perspective. Leiden: Koninklijke Brill NV.

Worker. 1890. The editorial mill. The Worker. 13 December 1890: 1-2.

Worker. 1901. A white Australia. The Worker. 30 March 1901: 2.

Worker. 1904. The white man's burden. The Worker. 24 December 1904: 1.

Worker. 1905. Some new year reflections. The Worker. 30 December 1905: 2.

Wright, Johnson K. 2002. Historical thought in the era of the Enlightenment. In Lloyd Kramer \& Sarah Maza (eds.), A companion to Western historical thought, 123-142. Oxford: Blackwell Publishers. DOI: 10.1002/9780470998748.ch7 